\section{The Effects of Using Concept Cartoons in Astronomy Subjects on Critical Thinking Skills among Seventh Grade Student ${ }^{*}$}

\author{
Filiz Demirci ${ }^{a}{ }^{*}$, Cengiz Özyürek ${ }^{b}$
}

\author{
Received: 20 September 2017 \\ Revised: 3 November 2017 \\ Accepted: 12 November 2017 \\ ISSN: 1307-9298 \\ Copyright (c) IEJEE \\ www.iejee.com
}

DOI: 10.26822/iejee.2017236119

\begin{abstract}
The objective of this study is to research the effects of using concept cartoons in the "Solar System and Beyond" unit, which is included in seventh grade science lessons, on students' critical thinking skills. The study group consisted of 58 students, selected using an appropriate sampling method, who were students in a state secondary school, which is close to the city centre. The study used a pre-test and post-test matched control group design. During the three-week-long experimental teaching process, the students in the control group $(n=30)$ were taught according to the curriculum of science lessons, while concept cartoons developed by the researchers were used with the students in the experimental group $(n=28)$. The Cornell Critical Thinking Test-Level X (CCT-X), as developed by Ennis \& Millman (1989), was used as the data collection tool. The results of the study showed decreases in the critical thinking skills scores of the students in the control group, while a statistically significant difference was found in the critical thinking skills of the students in the experimental group. In addition, a statistically significant difference was observed in favour of the experimental group when comparing the CCT-X scores of the experimental group's use of concept cartoons and those of the control group's used existing teaching methods.
\end{abstract}

Keywords: Solar system and beyond, astronomy education, critical thinking, concept cartoons.

\section{Introduction}

Astronomy is a field of science that gives us historical information about humankind and data on the structure and history of the universe in order to understand what kind of a future the universe will have, as well as the phenomena taking place in the sky. In short, it is a field of science that is interested in every foundation stone of the universe, from the smallest to the biggest. As one of the oldest sciences, astronomy offers individuals scientific thinking skills and plays a role in their capacity to make judgements about the universe (Ministry of Education [MoNE], 2010). Astronomy enables human beings to understand the universe. It is necessary for human beings to make deductions about events and phenomena by using the information they have, their logic, scientific methods and critical thinking skills in order to be able to gather scientifically acceptable information about the world and they universe they live in. It is especially important for individuals to use critical thinking skills in order to be able to find out which of the existing assertions available to believe in.

Ennis (1985, p. 45) defined critical thinking as "reasonable and reflective thinking which focuses on what one believes in or what to do". Evancho (2000) defined critical thinking as the ability of "the individual to make analytic and assessment-oriented conscious judgments and express these judgments to reach a decision as to that s/he shall do or believe" (quoted in Seferoğlu \& Akbıyık, 2006: 195).
According to Ennis (1991), critical thinking includes the following features:

1. Clarity: disposition to being clear about the meaning of what is expressed or written

2. Focus: disposition to finding out and continuing to focus on the question or the result

3. Total situation: disposition to consider the situation in all its aspects

4. Reasons: disposition to look for and present reasons to justify logical reasoning

5. Trying to be well informed: disposition to present proof about a subject

6. Alternatives: disposition to look for different ways to understand a situation

7. Precision: disposition to try to obtain definite information to the extent permitted by the subject

8. Self-awareness: disposition to try to be self-aware about each of one's primary needs

9. Open-mindedness. disposition to be open-minded by thinking of different perspectives other than one's own

10. Caution: disposition to refrain from making an important judgement when evidence and reason are not sufficient

11. Non-scepticism: disposition to have a position or change it when evidence and reasons are sufficient

12. Using one's abilities: disposition to foster and use critical thinking skills

According to educational philosophy, critical thinking is an indispensable part of education, rather than simply being

\footnotetext{
a,* Corresponding author: Filiz Demirci, Department of Mathematics and Science Education, Ordu University, Ordu, Turkey. E-mail: filizdemirci@odu.edu.tr

${ }^{\mathrm{b}}$ Department of Mathematics and Science Education, Ordu University, Ordu, Turkey. E-mail: cengizozyurek@odu.edu.tr
} 
another option (Norris, 1985). Today, around the world, it is widely accepted that a society that is not dominated by critical thinking cannot be a developed society (Aybek, 2007). As the future leaders or decision makers in our society, today's students should be able to think openly, with a sceptical and questioning attitude when deciding on social problems, while being able to assess the arguments of an issue critically and reach healthy decisions (Tümay \& Köseoğlu, 2011).

Critical thinking enables students to synthesize, analyse and assess students' thoughts, beliefs and actions in order to guide them better. Critical thinking has become both a result and a necessity for human beings who are experiencing fast changes and who need and desire to predict the future and prepare for it ideationally (Aybek, 2007).

Besides, critical thinking and critical thinking skills can be earned and can be developed through education (Schafersman, 1991). Today, critical thinking, which is at the forefront of learning and teaching thinking skills, is an important factor in terms of increasing students' academic achievement, encouraging them to produce information, enabling them to learn by being less dependent on textbooks and teachers, helping them to assess social structures and encouraging them to change these structures (Anonymous, 2016). Thus, learning and teaching critical thinking should have an important place. Tsai, Chen, Chang and Chang (2013) concluded that developing students' critical thinking skills helped them to comprehend information delivered in science lessons. A great number of previous studies on this subject shows that students' critical thinking skills and their academic performance/achievement are closely related. In other words, students with higher critical thinking skills are more successful in lessons (Ip, Lee, Lee, Chau, Wootton \& Chang, 2000; Giancarlo \& Facione, 2001).

Browne \& Freeman (2000) stated that critical thinking can be taught to students with their active participation. One of the teaching techniques that encourages students participate actively in class is the use of concept cartoons, which gives them a discussion environment. Concept cartoons can be used as a teaching tool to encourage students to think critically and participate in discussions (Cho \& Reich, 2008).

Along with learning scientific knowledge, enjoying the lesson is also a goal of science education. Within this context, humorous teaching materials can make science lessons more fun and thus help students to enjoy science (Özdemir, 2017). In addition, according to Percy (2006), studies have shown that students who are interested in the teaching materials learn more effectively, while Jiwaji (2016) stated that astronomy encouraged students to increase their interest in science. In light of all these statements, while taking into consideration the principle that "students learn more when they are interested in the subject or when they are motivated", it is important to use concept cartoons developed for astronomy subjects.

Concept cartoons represent a method that can be used as a learning, teaching and assessment technique in science teaching (Bahrani \& Soltani, 2011; Chin \& Teou, 2009;
Dabell, 2008; Kabapınar, 2005; Keogh, Naylor \& Wilson, 1998; Keogh \& Naylor, 1999; Naylor \& Keogh, 2010, 2012). Dabell (2004) expressed the advantages of concept cartoons when used as teaching tool as follows:

- They give students the opportunity to question their ideas, to extend their thoughts and to bring different perspectives to events.

- They help to create a discussion environment and active participation of students.

- They guide students in solving the problems they encounter in their daily lives.

- They reveal the uncertainties and misconceptions in students' minds.

- They can be used in activities conducted to combine or extend subjects (quoted in Balım, İnel \& Evrekli, 2008).

Regarding Dabell's expressions, it can be said that a wellformed concept cartoon will contribute to students' mental development, especially to their critical thinking skills. In addition, Browne \& Freeman (2000), classes in which critical thought is dominant generally have four characteristics: "frequently asked questions", "growing tension", "exposure with the possibility of reached conclusions" and "encouraging active learning". Bahrani and Soltani (2011) stated that, by using concept cartoons: 1. students' attention can be engaged by the words and pictures in the concept cartoon, 2. the motivation and attitude to learn can increase positively, 3. they are useful and alternative tools for the cognitive development of students, 4. they help to develop students' higher order critical thinking skills, 5 . they represent a starting point to make students think about their ideas or feelings about a situation, and 6 . they help to create a discussion environment in the classroom.

This instructional technique can benefit students by means of motivating effects of humor and creative drawing, along with mental manipulations (Zousel, Rule \& Logan, 2013). Presenting a discussion environment with student-centred teaching plays an effective role in developing students' critical thinking skills (Alkaya, 2006). Besides enabling students to think freely and express themselves or their ideas in writing or orally, concept cartoons also develop students' critical thinking skills (Özlap, 2006). Within this context, Özalp (2006) stated that, during the process of interpreting the cartoons, students make connections with the drawings, create stories in their minds by interpreting these connections and think critically by using this method.

A great number of studies in which the use of concept cartoons is approached as a teaching method has shown that concept cartoons encourage students to think critically and create critical discussions by encouraging them to participate in the lesson (Balım et al., 2008; Kabapınar, 2005; Keogh \& Naylor, 1999; Keogh, Naylor, de Boo \& Feasey, 1999). Kabapınar (2005) concluded that using concept cartoons as a teaching method increased students' participation in lessons, facilitated critical discussion and encouraged them to research the validity of the thoughts presented. Balım et al. (2008) studied the effect of concept cartoons in science education on students' academic achievement and questioning-based 
learning skills, concluding that using concept cartoons was effective in developing students' critical thinking skills.

When the literature on the teaching of astronomy subjects is reviewed, it can be seen that, rather than being confined to the teaching of conceptual definitions, it is necessary to use observations, discussions and modelling, for example, to help the students make interconceptual relations in a meaningful way (Diakidoy \& Kendeou, 2001; Zeilik et al., 1997). Percy (1998) stated that, although astronomy is taught extensively in primary education, teachers have little or no information about astronomy, while the teaching techniques used are generally confined to coursebooks. In addition, according to the author (1998), in many studies conducted on astronomy teaching, it was claimed that telescopes and computers are not necessary, while hands-on activities, which are cheaper, are recommended as being more effective. On the other hand, astronomy education plays an important role in developing the critical thinking skills of individuals (Uçar \& Demircioğlu, 2011). In the light of all these views, the objective of this study is to show whether a teaching method in which concept cartoons are used for teaching astronomy subjects, which include several abstract concepts, will result in a significant difference in students' critical thinking skills. In addition, when the literature was reviewed, no studies were found that discussed the effect of using the concept cartoon technique in the "Solar System and Beyond" unit of seventh grade science lessons on students' critical thinking. It is thought that this study will determine the effectiveness of the concept cartoon technique on students' critical thinking skills and present ideas to teachers, researchers and programme makers.

\section{Problem Statement}

This study basically tries to answer the question: "What are the effects of using the concept cartoon technique in the "Solar System and Beyond" unit in the "Earth and Universe" subject of seventh grade science lessons on students' critical thinking skills?"

\section{Subproblems}

In the "Solar System and Beyond" unit of seventh grade science lessons;

- Are there statistically significant differences in the The Cornell Critical Thinking Test, Level X (CCT-X) pre-test and post-test scores for the control group students taught with the existing teaching method?

- Are there statistically significant differences in the CCT-X pre-test and post-test scores for the experimental group students used the concept cartoon?

Are there statistically significant differences between the CCT-X pre-test scores for the control group students taught with the existing teaching method and the experimental group students used concept cartoons?

\section{Methodology}

\section{Study Design}

The quasi-experimental design was used in this study. Quasi-experimental design is a type of design in which subjects are randomly assigned to different experimental and control groups. The most important advantage of this design is the possibility of randomly assigning existing groups into different groups when it is impossible to randomly assign, especially in the social sciences (Fraenkel et al., 2012). The design of this study is given in Table 1.

Table 1. Pre-test and Post-test Semi-Experimental Design with Control Group

\begin{tabular}{cccc}
\hline Group & Pre-test & Teaching Method & $\begin{array}{c}\text { Post- } \\
\text { test }\end{array}$ \\
\hline Experimental & CCT-X & $\begin{array}{c}\text { Concept Cartoon } \\
\text { Technique } \\
\text { Control }\end{array}$ & CCT-X \\
CCT-X & $\begin{array}{c}\text { Existing Teaching } \\
\text { Methods }\end{array}$ & CCT-X \\
\hline
\end{tabular}

\section{Study Group}

The study was conducted in a state secondary school close to the city centre with a middle socio-economic level. The sample was determined using an appropriate sampling method among the state schools in the city of Ordu, which was regarded as the universe of this study. Two classes were chosen randomly from seventh graders in the school. The experimental group consisted of 28 students (17 girls, 11 boys), while the control group consisted of 30 students (13 girls, 17 boys). Seventh graders were chosen as the study group since the unit "Solar System and Beyond", in which astronomy subjects are taught to a great extent, is taught at this grade.

\section{Data Collection Tool}

The CCT-X, developed by Ennis \& Millman (1989) for between fourth and 14th grade was used as the data collection tool. The test has a total of 71 multiple choice questions and five subdimensions (induction, deduction, making assumptions, making observations and questioning the credibility of sources). The test was adapted into Turkish by Akar, Yüve and Acun, while the Cronbach alpha reliability coefficient value of the test was detected as 0.71 (quoted in Akar, 2007). The data were collected using the CCT-X as a pre-test for the control and experimental groups before the experimental process and as a post-test for both groups after the experimental process. As a result of the reliability analysis of this sample group, the Cronbach alpha reliability coefficient of the test was found to be 0.79 .

\section{Developing Concept Cartoons}

Concept cartoons, which were used as teaching tool in the experimental group, were prepared by the researchers, based on the content of subjects/concepts in the "Solar System and Beyond" unit of seventh grade science lessons (MoNE, 2013). Common cartoon characters and the Scratch ${ }^{1}$ program were used to create the concept

\footnotetext{
${ }^{1} A$ free program in which users can create interactive students, games and animations of their own.
} 
cartoons. A total of 22 concept cartoons (three on space and the universe, one on light years, one on star clusters, four on stars, four on the solar system and planets, two on comets, one on meteors, one on galaxies, one on telescopes, one on space pollution, one on astronomers/astronauts, and two on astronomy/astrology concepts) were created, with the aim of developing students' critical thinking skills.

The prepared concept cartoons were examined by a lecturer in the Science Education Department and a professor in the Astronomy and Space Sciences Department in terms of their conceptual framework and the scientific expressions in the speech balloons. The experts stated that all of the concept cartoons (without any exclusion) could be used in the pilot study after the recommended editing was made. In addition, care was taken to create the concept cartoons in a way that they would help to develop students' critical thinking skills. For this purpose, the researchers tried to create at least three speech balloons (characters), which included different ways of thinking with content, in order to facilitate a discussion environment in the classroom. An example of the concept cartoons used in experimental teaching process is given in Appendix.

\section{Pilot Study}

Before the study was conducted, the required permissions were sought from the Ordu Provincial Directorate for National Education, from the competent ethical board and from the directorate of the school in which the study was to be conducted in order to realize the legal procedures. In addition, oral consent was obtained from each teacher and student to confirm their willingness to participate in the study voluntarily.

The study was completed in four weeks and ran as follows: informing the students and teachers about the concept cartoon technique, the pilot study, pre-tests, experimental processes and post-tests. All the applications in the study were conducted in the classroom environment. Firstly, the students in the experimental group and the teachers were informed about the application process involving concept cartoons before the teaching was carried out, after which the pilot study was conducted with the cartoons in order to determine the comprehensibility of the cartoons by the students, as well as the estimated application period of a cartoon. Within this context, two weeks before the experimental application, the lesson plan and 22 concept cartoons were provided to the teacher. In addition, informative interviews were made with the teacher about the experimental application outside the learning-teaching process. The pilot study, which lasted for a week (four hours of class), was delivered to the students in the experimental group on the subject of the "transformation of electrical energy" by using the cartoon concept. After the researchers observed each lesson in the pilot study without participating, they gave feedback to the teacher or students about the problems and shortcomings that they noticed about the application.

\section{Experiment}

One week before the experiment was conducted, the CCT-X was given to both groups as a pre-test by the science teacher. The teaching, which lasted for three weeks (12 hours of class) in both groups, was conducted in line with the existing curriculum for the control group, while concept cartoons were used for the experimental group. After the experiment was conducted, the CCT-X was given to both groups as a post-test by the science teacher. During this process, the researcher made no interventions in the classroom.

When the teacher came to class, he started by projecting the concept cartoon on the board so that all the students could see easily it. The teacher introduced the characters and the thoughts they advocated to students. After this, the teacher asked which characters' thoughts the students agreed with and why. All the students in the classroom were given the chance to express their ideas, which were or were not in the concept cartoon, openly and easily. Thus, the students were given the chance to be aware of different views, as well as question their own knowledge and views. Following a class discussion, the teacher invited the students to suggest a method to research the correctness of the thoughts they advocated. During this process, while the students were researching the correctness of their thoughts, the teacher offered no scientific explanations about the concept. At the end of the method, the students discussed their research results in the classroom with the teacher and reached a conclusion.

\section{Data Analysis}

The data obtained with the CCT-X in both groups were sent to the company that had the copyright for using the test in Turkey, which calculated the total scores for each student taking the test. The SPSS 22.0 program was used in the analysis of the data.

The t-test was used to find out whether there were significant differences between the scores for the control and experimental groups. Firstly, the paired sample t-test was used to find out whether there were significant differences in the pre-test and post-tests scores for the groups, while an independent samples t-test was used to find out whether there were significant differences between the groups (Field, 2009). For the analysis of the data, Shapiro-Wilk normality test values (since the group size was less than 50 ) were used to test the normality assumption, while the Levene test results were examined to test the equality assumption of group variances. In the analysis of the data for the first and second subproblems, which showed a normal distribution and equal group variance, the dependent groups t-test was used. In the two-way ANOVA for mixed measurements, there are two different factors to successively measure in both groups (experimental and control) using the pre-test and the post-test. By carrying out this analysis, it can be determined whether: 1 . there is a significant difference between the total pre-test and post-test scores of both groups measured, irrespective of the difference between successive measurements, 2 . there is a difference between successive measurements of all participants, 
irrespective of groups, and 3. the change between the pre-test and post-test scores is significantly different in terms of the experimental and control groups (Can, 2014: 247).

In addition, the effect size (partial eta squared value) of the data, showing a significant difference in the analyses, was calculated. The effect size indicates how much the independent variable explains the total variance in the dependent variable (Field, 2009). It can be said that the partial eta squared (partial $\left.\eta^{2}\right)$. The level of significance $(p)$ was taken as 0.05 .
Results

\section{Results of the First Subproblem}

The data obtained from the subproblem, "Are there statistically significant differences in the CCT-X pre-test and post-test scores for the control group students taught with the existing teaching method in in the 'Solar System and Beyond' unit of seventh grade science lessons?", were analysed with the dependent groups t-test. The descriptive results of the students in the control group for the CCT-X are given in Table 2.

Table 2. Descriptive Analysis Results of the CCT-X Pre-test and Post-test Scores for the Control Group

\begin{tabular}{lrrrrrrrr}
\hline Application & $N$ & Min. & Max. & $\boldsymbol{M}$ & sd & Variance & Skewness & Kurtosis \\
\hline Pre-test & 30 & 21.00 & 52.00 & 38.27 & 6.67 & 44.55 & -0.50 & 0.83 \\
Post-test & 30 & 19.00 & 52.00 & 37.57 & 7.01 & 49.15 & -0.34 & 0.83 \\
\hline
\end{tabular}

The lowest score one can get from the CCT-X is 0 , while the highest score is 71. The lowest pre-test score for the students in the control group was 21.00, while their highest pre-test score was 52.00; and their lowest posttest score was 19.00, while their highest post-test score was 52.00. When Table 2 is examined, it can be seen that the post-test mean scores for the students in the control group $\left(M_{\text {post-test }}=37.57\right)$ are relatively lower when compared with their pre-test score means ( $M_{\text {pre-test }}=$ 38.27). In addition, it can be seen that the skewness and kurtosis values of the normality distribution of the pretest and post-test scores for the control group students were between -1 and +1 (Table 2). However, normality test results should also be examined to determine whether the data of the control group are normally distributed. Normality test results of the CCT-X pre-test and post-test for the control group are given in Table 3.

When Shapiro-Wilk values are examined, it can be seen that the CCT-X pre-test and post-test results for the control group are normally distributed ( $p>0.05$ ) (Table 3 ). In addition, when the skewness and kurtosis values in Table 2 were assessed with the values determined by the normality test, it was found that the parametric tests were suitable for the analysis of the pre-test and post-test score means of the control group.

Table 3. Normality Test Results of the CCT-X Pre-test and Post-test for the Control Group

\begin{tabular}{lcccccc}
\hline \multirow{2}{*}{ Application } & \multicolumn{3}{c}{ Kolmogorov-Smirnov } & \multicolumn{3}{c}{ Shapiro-Wilk } \\
\cline { 2 - 7 } & Statistic & sd & $p$ & Statistic & sd & $p$ \\
\hline Pre-test & 0.14 & 30 & 0.12 & 0.97 & 30 & 0.52 \\
Post-test & 0.13 & 30 & 0.17 & 0.97 & 30 & 0.51 \\
\hline
\end{tabular}

Thus, the independent groups t-test was used to find out whether there were statistically significant differences between the CCT-X pre-test and post-test score means of the control group. The independent groups t-test analysis results of the pre-test and post-test scores for the control group are given in Table 4.

Table 4. $t$-test Results of the CCT-X Pre-test and Post-test for the Control Group

\begin{tabular}{lccccccc}
\hline Test & Application & $\boldsymbol{N}$ & $\boldsymbol{M}$ & sd & df & $\boldsymbol{t}$ & $\boldsymbol{p}$ \\
\hline \multirow{2}{*}{ CCT-X } & Pre-test & 30 & 38.27 & 6.67 & 29 & 0.87 & 0.40 \\
\hline
\end{tabular}

When Table 4 is examined, it can be seen that there is no statistically significant difference between the pre-test and post-test scores for the students in the control group. It can be seen that the CCT-X post-test score means ( $M_{\text {post- }}$ test $=37.57)$ are lower when compared with the pre-test score means $\left(M_{\text {pre-test }}=38.27\right)$. This result can mean that the teaching process conducted with the existing teaching methods has no positive influence on increasing the critical thinking test scores for the students.

\section{Results of the Second Subproblem}

The data obtained from the subproblem, "Are there statistically significant differences in the CCT-X pre-test and post-test scores for the experimental group students used the concept cartoon in the 'Solar System and Beyond" unit of seventh grade science lessons?", were analysed with the dependent groups t-test. The descriptive results of the students in the experimental group for the CCT-X are given in Table 5 . 
Table 5. Descriptive Analysis Results of the CCT-X Pre-test and Post-test Scores for the Experimental Group

\begin{tabular}{lccccccrr}
\hline Application & $N$ & Min. & Max. & $\boldsymbol{M}$ & sd & Variance & Skewness & Kurtosis \\
\hline Pre-test & 28 & 19.00 & 42.00 & 31.10 & 5.38 & 28.91 & -0.30 & 0.03 \\
Post-test & 28 & 21.00 & 44.00 & 34.50 & 6.88 & 47.37 & -0.54 & -0.91 \\
\hline
\end{tabular}

The lowest score one can get from CCT-X is 0 , while the highest score is 71 . It can be seen that the lowest pre-test score for the students in the experimental group was 19.00, while their highest pre-test score was 42.00; and their lowest post-test score was 21.00, while their highest post-test score was 44.00 . When Table 5 is examined, it can be seen that the post-test mean scores for the students in the experimental group $\left(M_{\text {post-test }}=34.50\right)$ are relatively higher when compared with their pre-test score means $\left(M_{\text {pre-test }}=31.10\right)$. In addition, it can be seen that the skewness and kurtosis values of the normality distribution of the pre-test and post-test scores for the experimental group students were between -1 and +1 (Table 5). However, the normality test results should also be examined to interpret whether the data of the experimental group are normally distributed. The normality test results of the CCT-X pre-test and post-test for the experimental group are given in Table 6 .

Table 6. Normality Test Results of the CCT-X Pre-test and Post-test for the Experimental Group

\begin{tabular}{lcccccc}
\hline \multirow{2}{*}{ Application } & \multicolumn{3}{c}{ Kolmogorov-Smirnov } & \multicolumn{3}{c}{ Shapiro-Wilk } \\
\cline { 2 - 7 } & Statistic & sd & $p$ & Statistic & sd & $p$ \\
\hline Pre-test & 0.11 & 28 & 0.20 & 0.98 & 28 & 0.80 \\
Post-test & 0.18 & 28 & 0.02 & 0.92 & 28 & 0.06 \\
\hline
\end{tabular}

When Shapiro-Wilk values are examined, it can be seen that the CCT-X pre-test and post-test results of the experimental group are normally distributed $(p>0.05)$ (Table 6). In addition, when the skewness and kurtosis values in Table 5 were assessed with the values determined by the normality test, it was found that parametric tests were suitable for the analysis of pre-test and post-test score means for the experimental group. Thus, the independent groups t-test was used to find out whether there were statistically significant differences between the CCT-X pre-test and post-test score means for the experimental group. The independent groups t-test analysis results of the pre-test and post-test scores for the experimental group are given in Table 7.

Table 7. T-test Results of the CCT-X Pre-test and Post-test for the Experimental Group

\begin{tabular}{|c|c|c|c|c|c|c|c|}
\hline Test & Application & $N$ & $M$ & sd & $d f$ & $t$ & $p$ \\
\hline \multirow{2}{*}{ CCT-X } & Pre-test & 28 & 31.11 & 5.38 & \multirow{2}{*}{27} & \multirow{2}{*}{-2.07} & \multirow{2}{*}{$0.04^{*}$} \\
\hline & Post-test & 28 & 34.50 & 6.88 & & & \\
\hline
\end{tabular}

$\star: p<0.05$

When Table 7 is examined, it can be seen that there is a statistically significant difference between the pre-test and post-test scores for the students in the experimental group in favour of the post-test scores $\left(t_{(27)}=-2.07\right.$, $p \leq 0.05)$. It can be seen that the CCT-X post-test score means $\left(M_{\text {post-test }}=34.50\right)$ are relatively higher when compared with the pre-test score means $\left(M_{\text {pre-test }}=31.11\right)$. This result could indicate that the teaching process conducted with the concept cartoons significantly increased the critical thinking test scores among students.

\section{Results of the Third Subproblem}

The data obtained for the third subproblem, "Is there statistically significant difference between the CCT-X pretest and post-test scores for the control and experimental group students used concept cartoons in the 'Solar System and Beyond' unit of seventh grade science lessons?", was analysed with the two-way ANOVA for mixed measures. Before the two-way ANOVA for mixed measures, primary hypotheses were tested. According to the first hypothesis, the dependent variable was found to be within the least interval scale. Since the CCT-X is a scale with equal intervals, this hypothesis was met. For the second hypothesis, the skewness and kurtosis values in
Table 8 and the Shapiro-Wilk normality test values in Table 9 were analysed. According to the results obtained, it can be said that the skewness and kurtosis values were between +1 and -1 , while the Shapiro-Wilk values met the normal distribution assumption; that is, the CCT-X scores met the normal distribution assumption in each subgroup. For the third hypothesis, the homogeneity of the variance for scores from the CCT-X of both groups was tested with Levene's test. It was found that the Levene's test result met the homogeneity of the variance in students' pre-test scores $\left[F_{(1,56)}=0.81, p>0.05\right]$ and posttest scores. Thus, assumptions were met for the two-way ANOVA analysis. As a result of the Box's test conducted for the fourth assumption, no significant difference was found between the paired combinations of measurement variances $\left[F_{(3,672164.56)}=2.26, p>0.05\right]$. As a result of Mauchly's Test of Sphericity conducted for the fifth assumption, it was found that the difference score in repeated measurements of the participants in any group differed significantly from difference scores for the other participants. Thus, all the assumptions of the two-way ANOVA for mixed measures were met. The descriptive analysis results of the CCT-X pre-test and post-test scores for students in the experimental and control groups are given in Table 8. 
Table 8. Descriptive Statistic Analysis Results Related to the CCT-X Pre-test and Post-test Scores

\begin{tabular}{lccccccrrr}
\hline Application & Group & $\boldsymbol{N}$ & Min. & Max. & $\boldsymbol{M}$ & sd & Variance & Skewness & Kurtosis \\
\hline \multirow{2}{*}{ Pre-test } & Control & 30 & 21.00 & 52.00 & 38.11 & 6.88 & 47.28 & -0.43 & 0.39 \\
& Experiment & 28 & 19.00 & 42.00 & 31.11 & 5.38 & 28.91 & -0.30 & 0.03 \\
\hline \multirow{2}{*}{ Post-test } & Control & 30 & 19.00 & 52.00 & 37.39 & 7.19 & 51.66 & -0.28 & 0.58 \\
& Experiment & 28 & 21.00 & 44.00 & 34.50 & 6.88 & 47.37 & -0.54 & -0.91 \\
\hline
\end{tabular}

Table 9. Normality Test Results of the CCT-X Pre-test and Post-test Mean Scores for the Experimental and Control Groups

\begin{tabular}{lcrrr}
\hline \multirow{2}{*}{ Application } & \multirow{2}{*}{ Group } & \multicolumn{3}{c}{ Shapiro-Wilk } \\
\cline { 3 - 5 } & & Statistics & df & $p$ \\
\hline \multirow{2}{*}{ Pre-test } & Control & 0.98 & 28 & 0.74 \\
& Experiment & 0.98 & 28 & 0.79 \\
\hline \multirow{2}{*}{ Post-test } & Control & 0.97 & 28 & 0.51 \\
& Experiment & 0.92 & 28 & 0.06 \\
\hline
\end{tabular}

In the study, it can be seen that the pre-test mean score for students in the experimental group, in which concept cartoons were used, was 31.11. Although their post-test mean score increased to 34.50 after the application, it can be seen that the pre-test mean score for students who were taught with the present application was 38.27, while their post-test mean scores decreased to 37.57 after the application (Table 8 and Figure 1). According to the results, it was found that there was an increase in the CCT-X scores for the experimental and control group students in favour of the experimental group following the experiment; however, the decrease in the CCT-X posttest scores for control group students was remarkable (Figure 2).

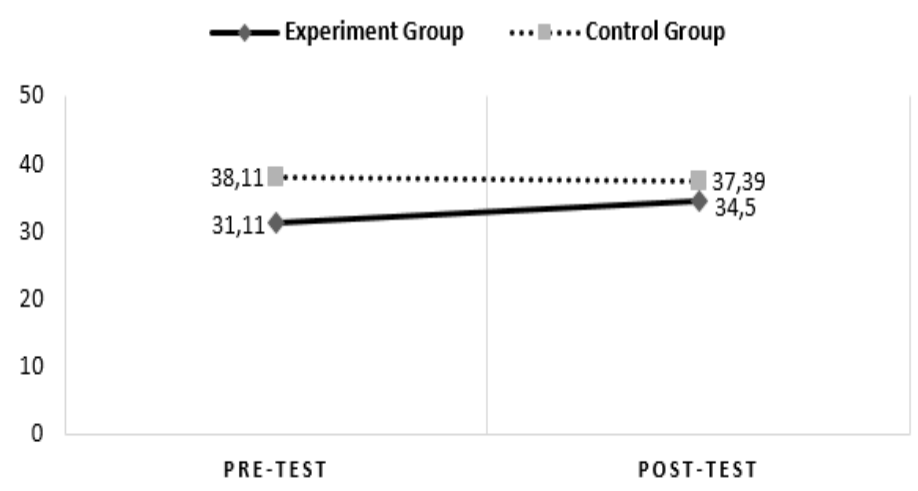

Figure 1. Comparison of the Results of the CCT-X Pre-test and Post-test Mean Scores for the Experimental and Control Groups

The results of the two-way ANOVA for mixed measures about whether there was a significant difference between the CCT-X pre-test and post-test mean scores for the experimental and control group students are given in Table 10.

Table 10. Results of the Two-way ANOVA for Mixed Measures of the CCT-X Pre-test and Post-test Scores for the Experimental and Control Groups

\begin{tabular}{lrrrrrrr}
\hline Source & $\begin{array}{r}\text { Sum of } \\
\text { Squares }\end{array}$ & df & Mean Square & $F$ & $p$ & $\eta^{2}$ & $\begin{array}{r}\text { Observed } \\
\text { Power }\end{array}$ \\
\hline Between Groups & & 57 & & & & & \\
$\quad$ Group (CC/PA) & 757.267 & 1 & 757.267 & 12.20 & $0.00^{*}$ & 0.18 & 0.93 \\
$\quad$ Error & 3475.423 & 56 & 62.061 & & & & \\
Within Groups & & 58 & & & & & \\
$\quad$ Measurement (Pre-test/Post-test) & 52.511 & 1 & 52.511 & 2.26 & 0.14 & 0.04 & 0.32 \\
$\quad$ Group*Measurement & 121.304 & 1 & 121.304 & 5.22 & $0.03^{*}$ & 0.09 & 0.61 \\
$\quad$ Error & 1301.489 & 56 & 23.241 & & & & \\
Total & \multicolumn{1}{c}{115} & & & &
\end{tabular}


An analysis of the two-way ANOVA for mixed measures was conducted in order to find out the effect of teaching with concept cartoons on the critical thinking skills of seventh graders. When Table 10 is examined, it can be seen that the critical thinking skills of the experimental group, in which concept cartoons were used, and the control group, which was taught with the present application, differed significantly between the pre-test and post-test stages, that is, the combined effect of being in the experimental and control groups and repeated measurement factors was found to be statistically significant $\left(F_{(1,56)}=5.22, p<0.05\right)$.

In this study, primary effect tests were also used to test the effect of teaching methods applied in the experimental and control groups on students' critical thinking skills. When Table 9 is examined in terms of the group primary effect, a statistically significant difference was found between the total mean scores of the CCT-X pre-test and post-test for the experimental and control group students $\left(F_{(1,56)}=12.20, p<0.05\right)$. In terms of the measurement primary effect, no statistically significant difference was found between the CCT-X mean scores for students from the pre-test to post-test stages, regardless of gender $\left(F_{(1,56)}=2.26, p>0.05\right)$. When the partial eta squared values were analysed, it was found that the group factor explained $18 \%$ of the variance in the students' critical thinking skills scores; while the value of group and measurement factors together explained 9\% of the variance in students' critical thinking skills scores (Table 10).

\section{Discussion, Conclusion and Recommendations}

According to the first results obtained in this study, it was found that the CCT-X pre-test scores for control group students, in which existing teaching methods were used, decreased when compared with the post-test scores, and there was no statistically significant difference (Table 4). Within this context, it can be said that the current teaching method applied to the control group students influenced the development of the critical thinking skills of seventh graders to a negative extent. The claim that the use of concept cartoons is effective in terms of facilitating an in-class discussion environment is supported by Seferoğlu and Akbıyık's (2006) view that the discussion technique is more relatively effective than simply lecturing in terms of giving students critical thinking skills. In addition, critical thinking skills depend on our ability to ask effective and smart questions, which delve deep into the subject and reveal its complex detail (Berman, 1985). In light of all these data, it can be said that, since the method applied in the control group is simply based on lecturing, students passively learn target behaviours as a result, without asking questions and not being able to express their thoughts freely. Furthermore, since there is no discussion environment and hardly any questions asked to cultivate the capacity to think, as preference is given to rote learning, the development of critical thinking skills is negatively influenced.

Another result of this study is the statistically significant difference between the CCT-X pre-test and post-test scores for the students in the experimental group, which favours the post-test (Table 7). This result shows that concept cartoons are effective in increasing the critical thinking skills of the experimental group students significantly. Wheeler and Collins (2003) examined the effects of concept cartoons used for preparing nursing students in their baccalaureate on students' critical thinking skills. Cho and Reich (2008) stated that cartoons can be used as teaching tools to encourage students to think critically and encourage them to participate in discussions. The findings of this and other studies reported in the literature support this claim from Cho and Reich (2008). In their study, Webb, Williams and Meiring (2008) concluded that concept cartoons were a promising teaching tool in terms of encouraging students to think and discuss. Köseoğlu (2009) concluded that using concept cartoons in social science lessons increased the critical thinking skills of seventh graders. The results of the study showed that concept cartoons were effective in helping the critical thinking skills of students.

Seferoğlu and Akbıyık (2006) emphasized the importance of open-ended questions and the method of discussion in developing students' critical thinking skills. This study, conducted with concept cartoons, was based on these two factors as a result of the nature of the method used. Students made connections with the concept cartoons displayed on the board by the teacher and given to them in paper form, then interpreted these connections and evaluated them. Thanks to this teaching method, students were guided to express their thoughts freely by being asked open-ended questions and were given the chance to discuss each other's views. Thus, it can be said that creating this kind of teaching environment is one of the reasons to explain the development of students' critical thinking skills. In addition, it can be stated that, since cartoons are colourful, witty and interesting, they encourage the active participation of students in lessons and thus play a contributive role in the development of critical thinking skills.

As a result of the study, it was found that there is a statistically significant difference in favour of the experimental group when comparing the critical thinking skill scores of the experimental group (in which concept cartoons were used) and the control group (in which existing teaching methods were used) in the seventh grade "Solar System and Beyond" unit (Table 9). Studies reporting parallel results with those for this study were also found (Miri, David \& Uri, 2007; Vieira \& TenreiroVieira, 2016). Miri, David and Uri (2007) conducted a three-year-long longitudinal study, which aimed to examine whether teaching strategies, designed to develop higher order thinking skills in science education, developed the critical thinking skills of 11th graders. As a result of the study, they concluded that teaching applications, which aimed to develop higher order thinking skills, led to no statistically significant development on critical thinking factors and the tendency to cultivate the critical thinking subdimensions of students when compared with traditional teaching methods. Based on these results, it has been stated that, if teachers try to apply higher order thinking skills (for example, by dealing with real-life problems in class, encouraging open-ended in-class discussions and thought experiments) with purpose and in a persistent way, this 
will create a better opportunity to develop critical thinking skills (Miri et al., 2007). Similarly, Vieira and Tenreiro-Vieira (2016) concluded that learning experiences within science learning and teaching, in which students aimed to be scientifically literate and were taught based on critical thinking, had a significant effect on the development of sixth graders' scientific literacy and critical thinking skills.

In light of the conclusions made by this study, the following recommendations can be made:

- Teachers have an important role to play in the development of critical thinking skills among students. Thus, practices such as pre-service teacher training programmes or in-service training can be increased in terms of quantity and quality.

- Studies can be conducted on the relationship between various methods and techniques used in the learning-teaching process for astronomy subjects and their impact on students' other thinking skills (problem-solving skills, reflective thinking skills, questioning skills).

- Various mixed research studies can be conducted to obtain more detailed information on students' critical thinking skills.

- In order to overcome the limitations of scales used in measuring critical thinking skills, studies should be conducted data diversity which data collection sets, such as observation, interview and document analysis, are used.

- This research consists of a three week teaching process. Longer-term longitudinal studies aimed at improving students' critical thinking skills can be conducted.

- In studies on providing students with and developing their critical thinking skills, multidimensional and extensive applications, blended with various teaching methods, rather than one teaching method, should be conducted, and their efficiency examined. In addition, the development of these applications can be observed by year on different sample groups, so that the efficiency of the technique applied can be assessed. In this way, the problems with the application can be identified and an effective method can be found to provide students with critical thinking skills.

- This research focuses on the development of critical thinking skills of students on subject-based topics in astronomy. Studies aiming at improving the critical thinking skills of students in faculty issues (physics, chemistry, biology, environmental education, socioscientific subjects, etc.) can be done.

\section{References}

Akar, Ü. (2007). Öğretmen adaylarının bilimsel süreç becerileri ve eleştirel düşünme beceri düzeyleri arasında ilişki [The relationship between student teachers' scientific process skills and critical thinking]. Unpublished master's dissertation, Institute of Social Sciences, Afyonkocatepe University, Afyon.
Anonymous. (2016). Eleştirel düşünme becerileri okulu kitapçı̆̆ [Critical thinking skills school booklet]. Retrieved from http://cocukuniversitesi.aydin.edu.tr/belgeler/elestirel. pdf.

Aybek, B. (2007). Eleştirel düşünmenin öğretiminde öğretmenin rolü [The role of the teacher in the teaching of critical thinking]. Bilim, Eğitim ve Düşünce Dergisi, 7(2). Retrieved from http://www.universitetoplum.org/text.php3?id=322.

Bahrani, T. \& Soltani, R. (2011). The pedagogical values of cartoons. Research on Humanities and Social Sciences, 1(4), 19-22.

Balım, A. G., İnel, D. \& Evrekli, E. (2008). Fen öğretiminde kavram karikatürü kullanımının öğrencilerin akademik başarılarına ve sorgulayıcı öğrenme becerileri algılarına etkisi [The Effects the Using of Concept Cartoons in Science Education on Students' Academic Achievements and Enquiry Learning Skill Perceptions]. Ilkögretim Online, 7(1), 188-202.

Berman, S. (1985). Thinking in context: teaching for open mindedness and critical understanding. In: Costa, A. L. (ed.). Developing Minds: A Resource Book for Teaching Thinking. Alexandria, VA: Association for Supervision and Curriculum Development.

Birisci P., Metin, M. \& Karakas, M. (2010). Pre-service elementary teachers' views on concept cartoons: a sample from Turkey. Middle East Journal of Scientific Research, 5(2), 91-97.

Browne, M. N. \& Freeman, K. (2000). Distinguishing features of critical thinking classrooms. Teaching in Higher Education, 5(3), 301-309.

Can, A. (2014). SPSS ile Bilimsel Araştırma Sürecinde Nicel Veri Analizi [Quantitative Data Analysis in Scientific Research Process with SPSS] (3rd Ed.). Ankara: Pegem Akademi Yayıncılık.

Chin, C. \& Teou, L. Y. (2009) Using concept cartoons in formative assessment: scaffolding students' argumentation, International Journal of Science Education, 31(10), 1307-1332.

Cho, S. \& Reich, G. A. (2008). New immigrants, new challenges: high school social studies teachers and English language learner instruction. The Social Studies, 99(6), 235-242.

Dabell, J. (2008). Using concept cartoons. Mathematics Teaching, 209, 34-36.

Diakidoy, N. \& Kendeou, P. (2001). Facilitating conceptual change in astronomy: a comparison of the effectiveness of two instructional approaches. Learning and Instruction, 11, 1-20.

Ennis, R. H. (1985). A logical basis for measuring critical thinking skills. Educational Leadership, 43(2), 45-48.

Ennis, R. H. (1991). Critical thinking: a streamlined conception. Teaching Philisopy, 14(1), 5-23. 
Field, A. (2009). Discovering statistics using SPSS (3rd Ed.). London: Sage Publication.

Fraenkel, J., Wallen, N. \& Hyun, H. H. (2012). How to design and evaluate research in education (8th Edition). McGrawHill: Boston.

Giancarlo, C. A. \& Facione, P. A. (2001). A look across four years at the disposition toward critical thinking among undergraduate students. The Journal of General Education, 50(1), 29-55.

Ip, W. Y., Lee, D. T. F., Lee, I. F. K., Chau, J. P. C., Wootton, Y. S. Y. \& Chang, A. M. (2000). Disposition towards critical thinking: a study of Chinese undergraduate nursing students. Journal of Advanced Nursing, 32(1), 84-90.

Jiwaji, N. T. (2016). Recognition of astronomy as an essential discipline at all levels of education in Tanzania. Rwanda Journal, 1(1), 82-87.

Kabapınar, F. (2005). Effectiveness of teaching via concept cartoons from the point of view of constructivist approach. Educational Sciences: Theory \& Practice, 5(1), 135-146.

Keogh, B. \& Naylor, S. (1999). Concept cartoons, teaching and learning in science: an evaluation. International Journal of Science Education, 21(4), 431-446.

Keogh, B., Naylor, S. \& Wilson, C. (1998). Concept cartoons: a new perspective on physics education. Physics Education, 33(4), 219-224.

Keogh, B., Naylor, S., De Boo, M. \& Feasey, R. (1999). Formative assessment using concept cartoons: initial teacher training in the UK. Research in Science Education: Past. Present and Future, 137-142.

Köseoğlu, M. (2009). Sosyal bilgiler dersinde karikatür kullanımının eleştirel düşünmeye etkisi [The effect of using caricature in social studieson critical thinking]. Unpublished master's dissertation, Institute of Social Sciences, Gaziosmanpaşa University, Tokat.

Miri, B., David, B. C. \& Uri, Z. (2007). Purposely teaching for the promotion of higher-order thinking skills: a case of critical thinking. Research in Science Education, 374), 353-369.

MoNE [Ministry of National Education] (2010). Ortaögretim astronomi ve uzay bilimleri dersi ögretim programı [High school astronomy and space science curriculum]. Ankara.

MoNE [Ministry of National Education] (2013). Ilköğretim kurumları (ilkokullar ve ortaokullar) fen bilimleri dersi $(3,4,5,6,7$ ve 8. sınıflar) ögretim programı [Primary education institutions (primary and secondary schools) science cource (3, 4, 5, 6, 7 and 8 classes) curriculum]. Ankara.

Naylor, S. \& Keogh, B. (2010). Concept Cartoons in Science Education (Second Edition). Sandbach: Millgate House.

Naylor, S. \& Keogh, B. (2012). Concept cartoons: what have we learnt? Paper presented at the Fibonacci Project European Conference, Leicester, UK. Retrieved from http://www.millgatehouse.co.uk/research/conce pt cartoons-research-ongoing.

Norris, S. P. (1985). Synthesis of research on critical thinking. Educational Leadership, 42(8), 40-45.

Özalp, I. (2006). Karikatür Tekniğinin Fen ve Çevre Eğitiminde Kullanılabilirliği Üzerine Bir Araştırma [A study on implementing the technique of caricature in science and environmental education]. Unpublished master's dissertation, Institute for Graduate Studies in Science and Technology, Celal Bayar University, Manisa.

Özdemir, E. (2017). Humor in Elementary Science: Development and Evaluation of Comic Strips about Sound. International Electronic Journal of Elementary Education, 9(4), 837-850.

Percy, J. R. (2006). Teaching Astronomy: Why and How? The Journal of the American Association of Variable Star Observers, 35(1), 248-254.

Percy, J. R. (1998). Astronomy education: an international perspective. Astrophysics and Space Science, 258, 347-355

Schafersman, S. D. (1991). An introduction to critical thinking. Retrieved from http://www.freeinquiry.com/critical-thinking.html

Seferoğlu, S. S. \& Akbıyık, C. (2006). Eleştirel düşünme ve ögretimi [Critical thinking and teaching]. Hacettepe Üniversitesi Eğitim Fakültesi Dergisi, 30, 193-200.

Trumper, R. (2006). Teaching future teachers basic astronomy concepts - seasonal changes - at a time of reform in science education. Journal of Research in Science Teaching, 43(9), 879-906.

Tsai, P., Chen, S., Chang, H., \& Chang, W. (2013). Effects of prompting critical reading of science news on seventh graders' cognitive achievement. International Journal of Environmental \& Science, 8(1), 85-107.

Tümay, H. \& Köseoğlu, F. (2011). Kimya öğretmen adaylarının argümantasyon odaklı öğretim konusunda anlayışlarının geliştirilmesi [The developing the understanding of chemistry teacher candidates about argumentation oriented teaching]. Türk Fen Eğitimi Dergisi (TUSED), 8(3), 105-119.

Uçar, S. \& Demircioğlu, T. (2011). Changes in preservice teacher attitudes toward astronomy within a semester-long astronomy instruction and four-yearlong teacher training program. Journal of Science Education and Technology, 20, 65-73.

Vieira, R. M. \& Tenreiro-Vieira, C. (2016). Fostering scientific literacy and critical thinking in elementary science education. International Journal of Science and Math Education, 14(4), 659-680.

Webb, P., Williams, Y. \& Meiring, L. (2008). Concept cartoons and writing frames: developing argumentation in South African science classrooms? African Journal of Research in SMT Education, 12(1), 417. 
Wheeler, L. A. \& Collins, S. K. R. (2003). The influence of concept mapping on critical thinking in baccalaureate nursing students. Journal of Professional Nursing, 196), 339-346.

Zeilik, M., Schau, C., Mattern, N., Hall, S., Teague, K. W. \& Bisard, W. (1997). Conceptual astronomy: a novel model for teaching postsecondary science courses. American Journal of Physics, 65(10), 986-996.

Zousel, M. L., Rule, A. C. \& Logan, S. R. (2013). Teaching primary grade students perfectionism through cartoons compared to bibliotherapy. International Electronic Journal of Elementary Education, 5(2), 199218. 
Appendix

Star and Planet Cartoon

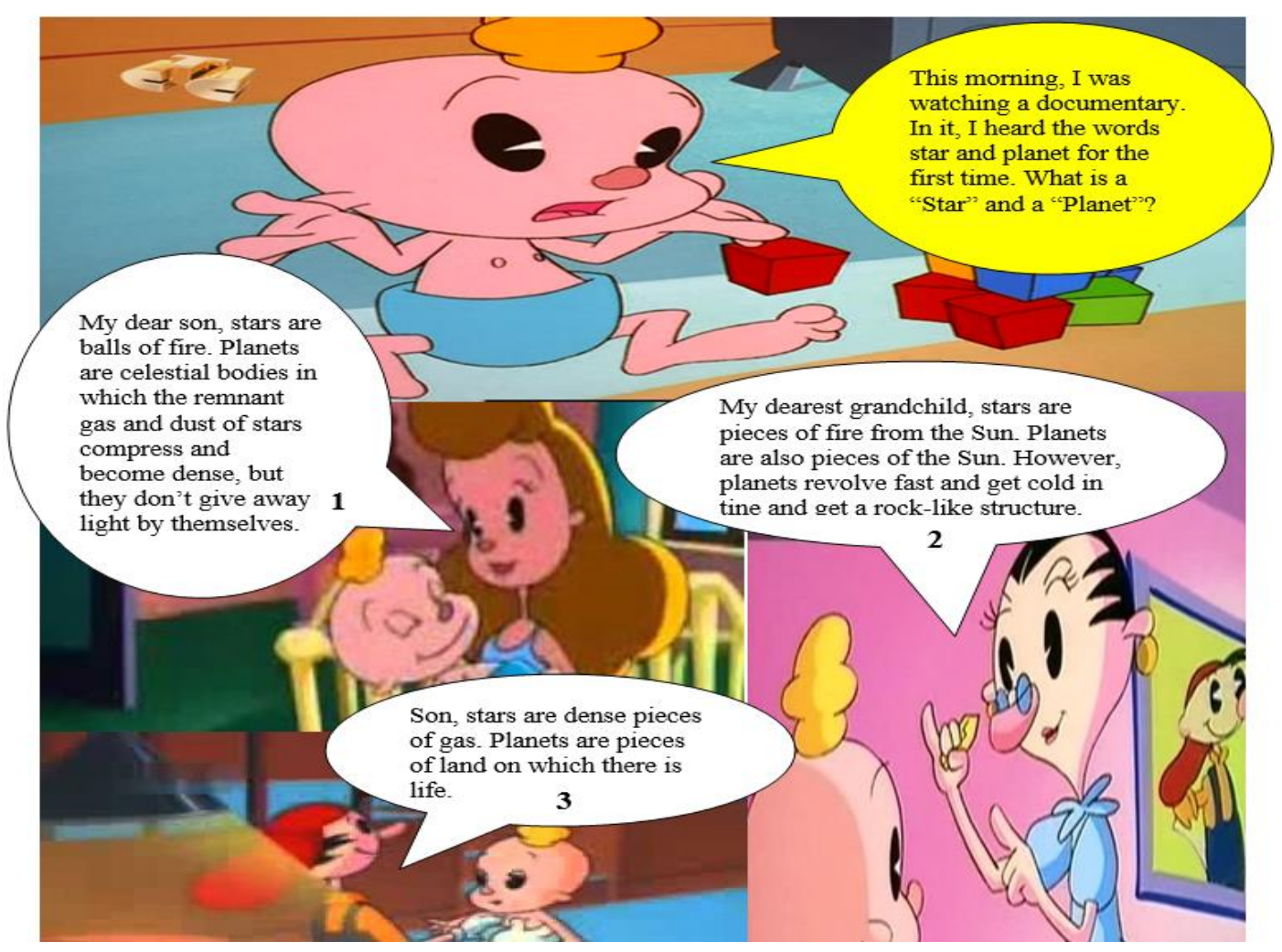

The visuals in this concept cartoon were created by using the cartoon series named "The Why Why Family" 